This PDF is a selection from an out-of-print volume from the National Bureau of Economic Research

Volume Title: Financial Markets and Financial Crises

Volume Author/Editor: R. Glenn Hubbard, editor

Volume Publisher: University of Chicago Press

Volume ISBN: 0-226-35588-8

Volume URL: http://www.nber.org/books/glen91-1

Conference Date: March 22-24,1990

Publication Date: January 1991

Chapter Title: Sustainability, Premia, and the Dollar

Chapter Author: Bankim Chadha, Steven Symansky

Chapter URL: http://www.nber.org/chapters/c11487

Chapter pages in book: (p. 231 - 258) 


\title{
Sustainability, Premia, and the Dollar
}

\author{
Bankim Chadha and Steven Symansky
}

\subsection{Introduction}

The 1980s witnessed the emergence of large and persistent current account imbalances among the major industrial countries in the intemational economic system. The United States is presently running a current account deficit of some $2 \frac{1 / 2}{2}$ percent of its gross national product (GNP), while Japan and Germany have current surpluses of similar order relative to their output levels. The persistence of these payments imbalances has given rise to unprecedented changes in the stocks of net foreign assets and liabilities of these countries. This process has transformed the United States from the largest net creditor country during most of the postwar period to the world's largest net debtor, with net foreign liabilities estimated officially at $\$ 630$ billion in $1989 .^{\prime}$ These developments have naturally raised fundamental questions about the magnitude and sustainability of the U.S. extemal position.

Extemal sustainability of a debtor country is usually defined as a nonexplosive path of net foreign debt relative to some scale variable, that attempts to measure the ability of the country to generate payments to nonresident creditors. In the case of the United States, sustainability could be defined as a stable - or as a path leading to the attainment of a stable - net foreign asset to GNP ratio. ${ }^{2}$ Consider now what the path of this ratio may look like with unchanged policies. ${ }^{3}$ By the balance of payments identity, the net stock of foreign assets, $F_{1}$, can be expressed as

Bankim Chadha is an economist in the Extemal Adjustment Division, Research Department of the Intemational Monetary Fund. Steven Symansky is a senior economist in the Extemal Adjustment Division, Research Department of the Intemational Monetary Fund.

The authors would like to thank Charles Adams, Michael Dooley, Glenn Hubbard, Cara Lown, Paul Masson, and Richard Meese for helpful comments. The views expressed here are those of the authors and should not be interpreted as representing those of the Intemational Monetary Fund. 


$$
F_{t}=B_{t}+(1+i) \cdot F_{t-1},
$$

where $B_{t}$ represents the trade balance and $i$ the nominal interest rate. Dividing through by nominal GNP, and using lower-case letters to denote ratios to nominal GNP, we have that

$$
f_{t}=b_{t}+\frac{(1+r)}{(1+g)} f_{t-1},
$$

or

$$
f_{t}-f_{t-1}=b_{t}+\frac{(r-g)}{(1+g)} f_{t-1},
$$

where $r$ represents the real interest rate, in terms of domestic goods, and $g$ the growth rate of real GNP. In 1989 the stock of net foreign assets is estimated to have been -12.0 percent of GNP and the trade balance -2.4 percent of GNP. Assuming a constant real interest rate, $r$, of 3.6 percentage points and a growth rate of real output, $g$, of 2.8 percent, it follows from (3) that for $r>g$, given that the $f$-ratio in 1989 was negative, the real interest burden per unit of output is positive. With a positive real interest burden, a necessary condition for the ratio to trough or stabilize over time is that the trade balance fall as a percentage of GNP and eventually go into surplus.

There is a whole set of exchange rate paths, policy changes, and behavioral responses that would lead to a stable $f$-ratio by pushing the balance of trade sufficiently into surplus to service the debt. One way of tackling the issue is to examine how much exchange rate depreciation is required for the ratio to stabilize. Figure 7.1 presents some illustrative paths for the $f$-ratio for alternative rates of depreciation of the dollar. The exchange rate paths represent nominal rates of depreciation of the dollar of 1,2 , and 3 percent a year against all currencies. The IMF's muLTIMOD model, which is described in the next section, was used to compute the improvements in the trade balance to GNP ratio, $b$, in response to an exogenous decline in the exchange rate. Nominal rather than real exchange rate paths were assumed so as to enable the model to endogenously determine the path of the real exchange rate and allow for other feedback effects. It should be noted that in all cases the extent of the real depreciation is substantially smaller, varying from 50 to 70 percent of the nominal depreciation.

Figure 7.1 shows that both the time required for the $f$-ratio to trough and the level at which it troughs can vary substantially. For a 1 percent rate of nominal depreciation, the ratio troughs at approximately -40 percent, albeit after a substantial period of time, by the year 2017. On the other hand, at a nominal rate of depreciation of 3 percent a year the ratio troughs at -20 percent by 1997. Note that for simplicity and purposes of comparison, the rate of depreciation has been kept constant up to the horizon presented. Therefore, the $f$-ratio continues to rise once it has troughed. There is of course no reason 


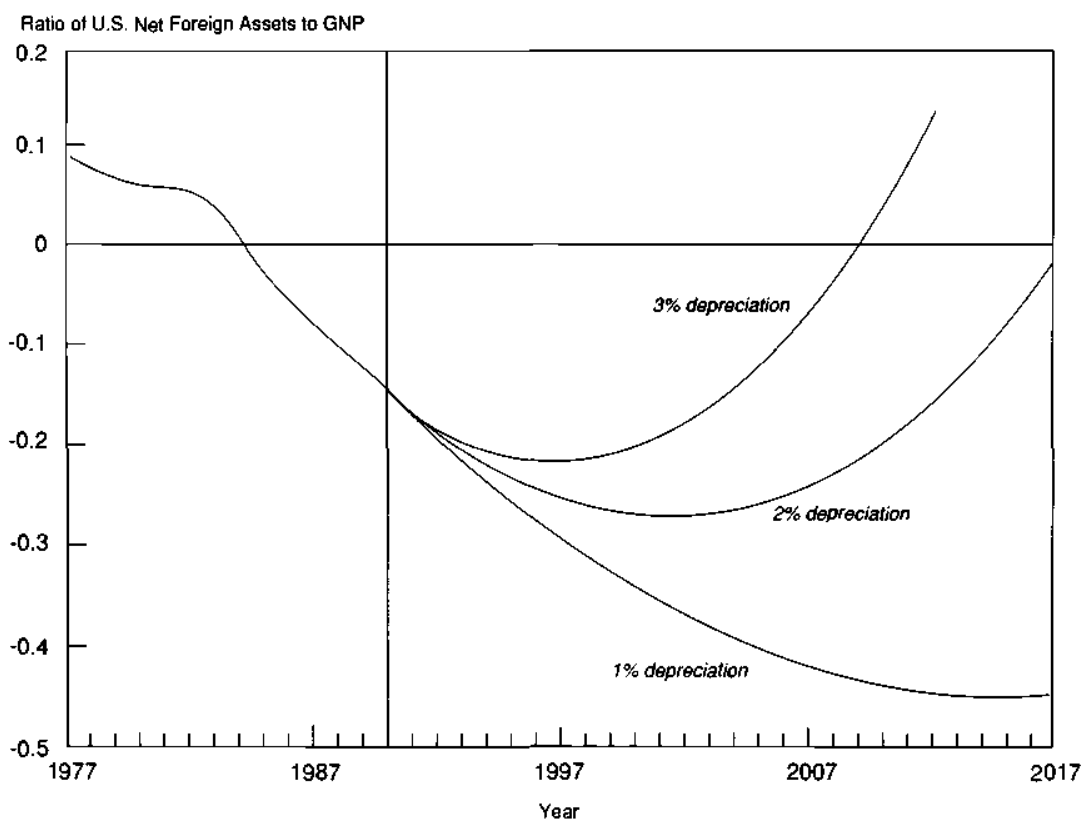

Fig. 7.1 U.S. net foreign assets under alternative exchange rate assumptions

why the exchange rate should continue to depreciate once the balance of trade is sufficiently in surplus to service the debt. If this were the case, the $f$-ratio would then likely stabilize.

The above discussion of sustainability, while showing that the $f$-ratio for the United States can easily trough or stabilize for reasonably small rates of depreciation of the dollar, ignores the issue of whether the ratio, even if it were to stabilize, would be consistent with the asset preferences of non-U.S. residents-the ultimate holders of the debt. The counterpart of the current and expected future decline in the U.S. $f$-ratio has been an increase in the share of holdings of net dollar assets in foreign portfolios. Recently, Dealtry and Van't dack (1989) have examined the impact of changes in the U.S. net extemal position on foreign portfolios. Their study suggests that the increase in the share of dollar assets in these portfolios has not been substantial. For example, they estimate that gross financial claims on the United States held by private residents of foreign industrial countries increased from 1.8 to 2.8 percent of total business-sector financial assets in these countries from 1981 to 1988, leaving a considerable potential for further increases. Moreover, they project that if the U.S. current account deficit were to persist at its 1988 level of $\$ 125$ billion, with no change in the pattem of net capital inflows, this share would still be less than 4.5 percent by 1993 . Figure 7.2 plots the counterpart of figure 7.1, expressing the ratio of net U.S. foreign assets as a percentage of 


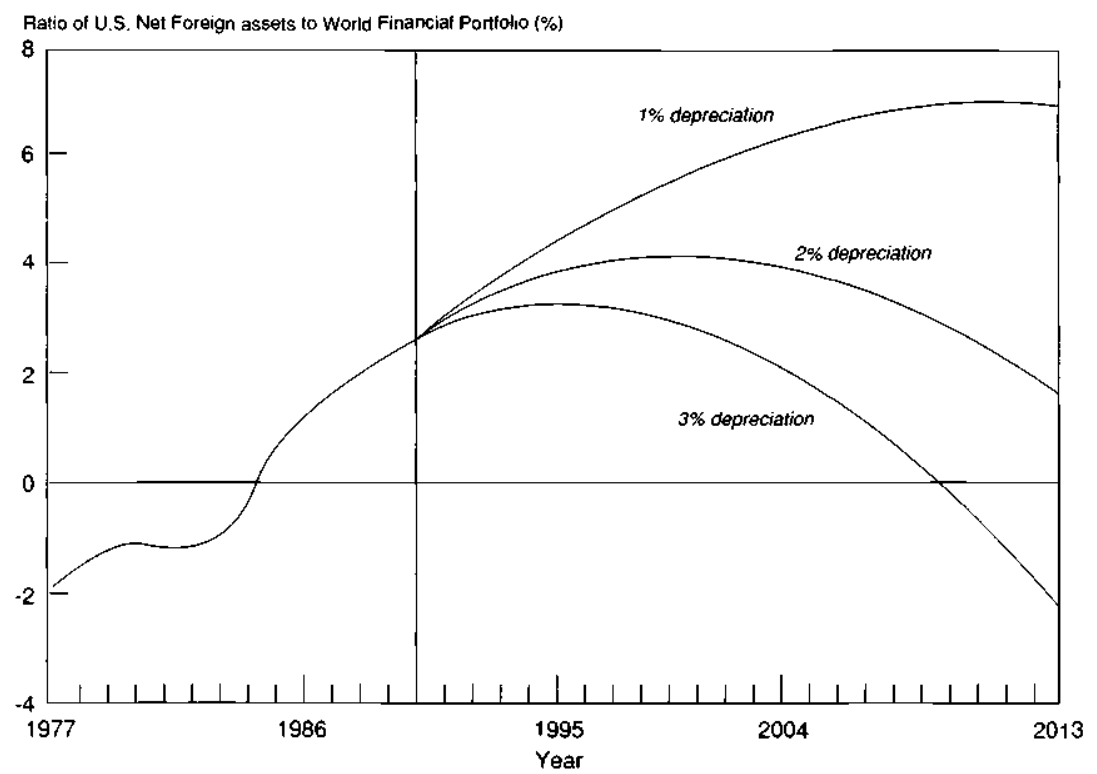

Fig. 7.2 U.S. net external liabilities in world financial portfolio

foreign industrial country financial portfolios, assuming for simplicity a constant financial portfolio to income ratio of three. ${ }^{4}$

The above suggests that (i) the U.S. net foreign asset to GNP ratio can stabilize or trough for reasonably small rates of depreciation of the dollar: and (ii) the associated increase in net U.S. liabilities as a proportion of foreign financial portfolios has been unprecedented but small. and is unlikely to increase substantially as a percentage of these portfolios if the U.S. $f$-ratio troughs or stabilizes. The final verdict on the sustainability of the U.S. external position. however. rests critically on the willingness of foreign investors to allow such an increase. however small. in their portfolios. A primary reason why foreign investors may become increasingly unwilling to hold additional quantities of U.S. debt is. as Dooley and lsard (1986) argue. the possibility of default. Krugman (1988, 1989a) and others have pointed out that for the United States. given its size and relatively limited dependence on foreign trade. the incentives to default may be greater than for other countries. This default does not have to take the form of an explicit refusal to repay. It could take the form of a differential tax levied by residence status. as in Dooley and Isard (1986)-for example. a tax on repatriated interest-or it could take the form of an inflation. or any other measure attempting to reduce the real value of the external debt to domestic residents. Moreover. there exists the possibility that foreign investors may decide to reduce the amount of U.S. debt they are willing to hold. This might happen for reasons that are either exogenous to the United States, for example. an increase in the attractiveness of investing 
elsewhere; or it could result from a perception that the path of the U.S. $f$-ratio was either unsustainable or going to become so, for example, because of an expected increase in the fiscal deficit. The situation is not unlike that for the Latin American debtors. Diaz-Alejandro (1984) attributes the build-up of Latin American debt during the 1970s to a one-time stock adjustment in international investors' portfolios, after which net inflows ceased abruptly, precipitating the "debt crisis" and consequent financial squeeze and depression of the 1980s in these economies. Therefore, a primary concern for the United States, resulting from the accumulation of foreign debt, is the exposure and vulnerability of the United States to a portfolio shift.

The purpose of this paper is to examine the effects of a portfolio shift against the dollar in a well-specified macroeconometric model for the industrial countries and the rest of the world. Section 7.2 briefly describes the model used. Section 7.3 then examines the effects of an exogenous shift in portfolio preferences against the dollar. Section 7.4 endogenizes the premium required to hold assets denominated in different currencies in world portfolios by making it a function of expected deviations of countries' $f$-ratios from arbitrarily specified levels. We examine what the path of the dollar might look like in such a scenario where, for example, there is a "run" on the dollar triggered by expectations that the U.S. external position will deteriorate. A conclusion that emerges from this section is that for reasonable declines in the U.S. $f$-ratio, such runs on the dollar would be stabilizing in that international investors could successfully impose on the U.S. an arbitrary $f$-ratio; and if it were to deviate, such a market reaction would bring it back. The economic consequences of such an imposed external adjustment are discussed. It is shown that small premiums can produce substantial movements of exchange rates and, over time, in $f$-ratios. Section 7.5 concludes the paper.

\subsection{Overview of MULTIMOD}

The simulations below use MULTIMOD, a multi-region econometric model developed by the IMF staff. While a more complete description of the model is available elsewhere, ${ }^{5}$ a brief description is presented here in order to help the reader understand the simulations.

MULTIMOD is a system of linked models designed to analyze the interactions of economic policies and developments among the industrial countries, as well as to examine how changes in economic conditions in the industrial world affect developing countries as a group. It is a dynamic Mundell-Fleming model that incorporates rational expectations in both goods and financial markets. However, policy can be effective in altering output because not all markets clear contemporaneously. In the goods market, for example, it is assumed that there are overlapping contracts and prices are sticky.

The system presently contains econometric models (estimated on the basis of annual data) for each of the G-7 countries (the United States, Canada, Ja- 
pan, Germany, France, Italy, and the United Kingdom), the smaller industrial countries as a group, high-income (capital-exporting) developing countries as a group, and other (capital-importing) developing countries as a group. Because of the limited degrees of freedom resulting from annual data, most of the equations were estimated using pooled cross-section time-series methods, and coefficients are often the same across countries unless rejected by the data.

The main linkages among the regions are the endogenous determination of prices and volumes of trade in goods and of exchange rates and interest rates. Each of the countries and regions produces manufactured goods which are imperfect substitutes. 1mports of manufactured goods by the industrial countries (and capital-exporting developing countries) are functions of relative prices and absorption. Imports by the capital-importing countries depend upon the amount of available foreign exchange (which depends, in turn, on exports and on the region's current and expected ability to service its debt). Each country's (or region's) imports of manufactured goods are allocated as exports across the other countries and regions through a trade matrix, with the initial pattern based on historical trading patterns. Trade shares adjust in response to changes in relative prices. It is assumed that all countries demand oil and that oil is homogeneous, with the developing countries as a group the residual suppliers. Non-oil primary commodities are produced by the developing countries, and the price of this aggregate good adjusts in the short run to clear the market, with production and supply eventually responding to changes in relative prices.

Domestic demand is composed of exogenous government spending on goods and services, as well as behaviorally determined private consumption and investment. Private consumption is derived from intertemporal utility maximization and is determined, in equilibrium, by total wealth (discounted future income plus financial assets); in the short run, it is affected by changes in disposable income. lnvestment is modeled as a gradual adjustment to an optimal level for the capital stock determined by the production technology. The equation is estimated in error-correction form, with the error-correction term specified as a forward-weighted average of output to capital and a separate term for the user cost of capital

The prices of domestically produced goods are determined in a pricemarkup Phillips curve relationship that incorporates overlapping wage contracts, so that prices are sticky. Current wage contracts are forward looking, incorporating anticipated future rates of inflation. Export prices are assumed to move with the domestic output price in the long run, but respond in the short run to price movements in export markets. 1mport prices are a weighted average of the export prices of other countries.

MULTIMOD models the demand for base money, rather than for a broader aggregate. An interest-rate reaction function is used to determine the stance of monetary policy in a country. For example, a fixed exchange rate system is 
imposed for those countries of the European Monetary System (EMS) who participate in the exchange rate mechanism (ERM). Italy, France, and the smaller industrial countries as a group are assumed to peg their currencies to the German deutsche mark by altering their interest rates in the short run (and, of course, money supplies). ${ }^{6}$ This policy regime results in a loss of monetary policy autonomy by all the ERM countries except Germany. In each of the other industrial countries, the monetary authorities set a target path for the monetary base. The actual path of the money supply is determined by the interest-rate reaction function which smoothes interest-rate changes in the short run. The specification of the interest-rate reaction function is used to avoid oscillations and large temporary changes in nominal interest rates (instrument instability), which result if the model is forced to track exactly a target path of the monetary base. In the long run, however, the actual money supply converges to the target path. With respect to monetary shocks, MULTIMOD has the important property that in the long run it is homogeneous of degree one in all nominal variables and degree zero in real variables.

Financial assets of the industrial countries are assumed to be perfect substitutes, and nominal exchange rates are determined by open interest parity. Long-term interest rates are specified as a weighted average of current and expected future short-term rates. An important feature of the model is that expectations about interest rates and exchange rates, as well as prices, are forward looking and consistent with the model's solution in future periods (i.e., expectations are "rational"). Thus current or expected future shocks to the model can result in rather substantial "jumps" in interest rates and exchange rates. These interest rate changes affect investment and consumption demand as well as the return on domestic and international debt stocks. The exchange rate primarily affects exports and imports through a change in relative prices.

A word of caution is necessary regarding the simulations in this paper. All the results are reported as a percentage or level deviation from a baseline value. The baseline for MULTIMOD assumes that over the long run, the noninterest government deficit and the trade balance tend toward balance, real variables grow at the real rate of interest, prices grow at the same rate as money, and thus all stock variables as a ratio to GNP stabilize. ${ }^{7}$ These assumptions were made to allow the model to simulate around a reasonable steady state. In general the model is relatively log linear and the choice of a baseline is not crucial. However, for the scenarios discussed in this paper, the baseline does affect the results because of the importance of baseline debt stocks in determining the change in the current account resulting from a change in interest rates. Since the U.S. net foreign asset position in the baseline is negative, the fiscal expansion described in section 7.4 results in a larger deterioration in the U.S. current account balance than if the baseline net foreign asset position were positive. This implies that the exchange rate change necessary 
to attain any particular improvement in the external position will be larger. While the baseline assumptions affect the magnitude of the results, they do not alter the basic issues described in this paper.

\subsection{Exogenous Depreciation of the Dollar}

In this section we consider the effects of an exogenous dollar depreciation in order to highlight some of the properties of MULTIMOD. ${ }^{8}$ In the IMF's World Economic Outlook in October 1988 and the OECD's Economic Outlook in June 1988, the effects on the world economy of a dollar depreciation, referred to as the "financial tensions" and "market enforced adjustment" scenarios, respectively, were discussed. In both cases, the analysis was motivated by the belief that the dollar was overvalued at the time, in light of current account imbalances that existed and the expectation that these imbalances would persist over the medium term. In the scenarios referred to above, the exchange rate is the outcome of an increase in the risk premium against dollar assets. ${ }^{9}$ In the next section we postulate behavior that can endogenously produce a dollar depreciation, but in the discussion below we restrict the simulation to an exogenous decline in the nominal value of the dollar, with a compensating movement in the risk premium.

In this simulation, we assume that the U.S. dollar depreciates by 10 percent in nominal terms against all the currencies of the industrial countries. Table 7.1 presents the results as deviations from a baseline for the United States, an aggregate of the other industrial countries, and the developing countries. ${ }^{10}$ Note that the real exchange rate depreciates by less than 10 percent as domestic prices adjust and offset some of the change in the nominal exchange rate, with the absorption deflator increasing by 3 percent above the baseline for the United States after a few years. On average, the real exchange rate depreciates by 7 percent. The trade balance worsens on impact because of a J-curve effect that lasts one year, but improves in both real and nominal terms over the medium and long run. The trade balance is, on average, about 1 percent of GNP above its baseline value, causing net foreign assets, as a percentage of GNP, to rise continuously over time.

The depreciation of the dollar requires an increase in the spread between U.S. and foreign interest rates. This increase in both real and nominal interest rates causes domestic demand to decline, both in the short run and over the medium term. Private consumption declines as a result of the increase in interest rates which reduces wealth (this decline in wealth more than offsets the increase in wealth arising from the increase in net foreign assets). The rise in the user cost of capital produces a permanent decrease in investment expenditures, and both the capital stock and capacity output decline over the long run. Although U.S. output rises in the short run because of an increase in net exports, it falls below the baseline after three years owing to the sustained 


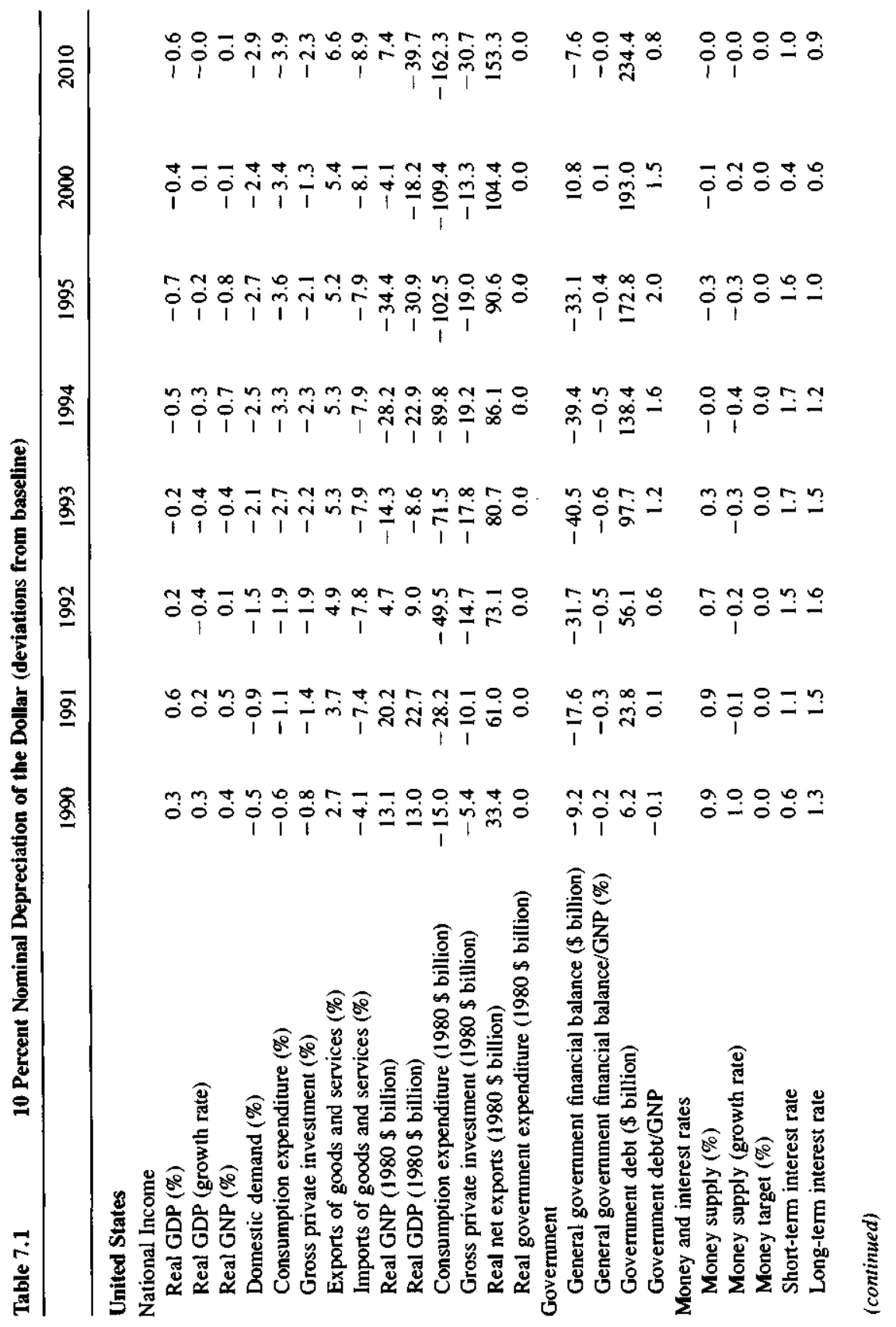




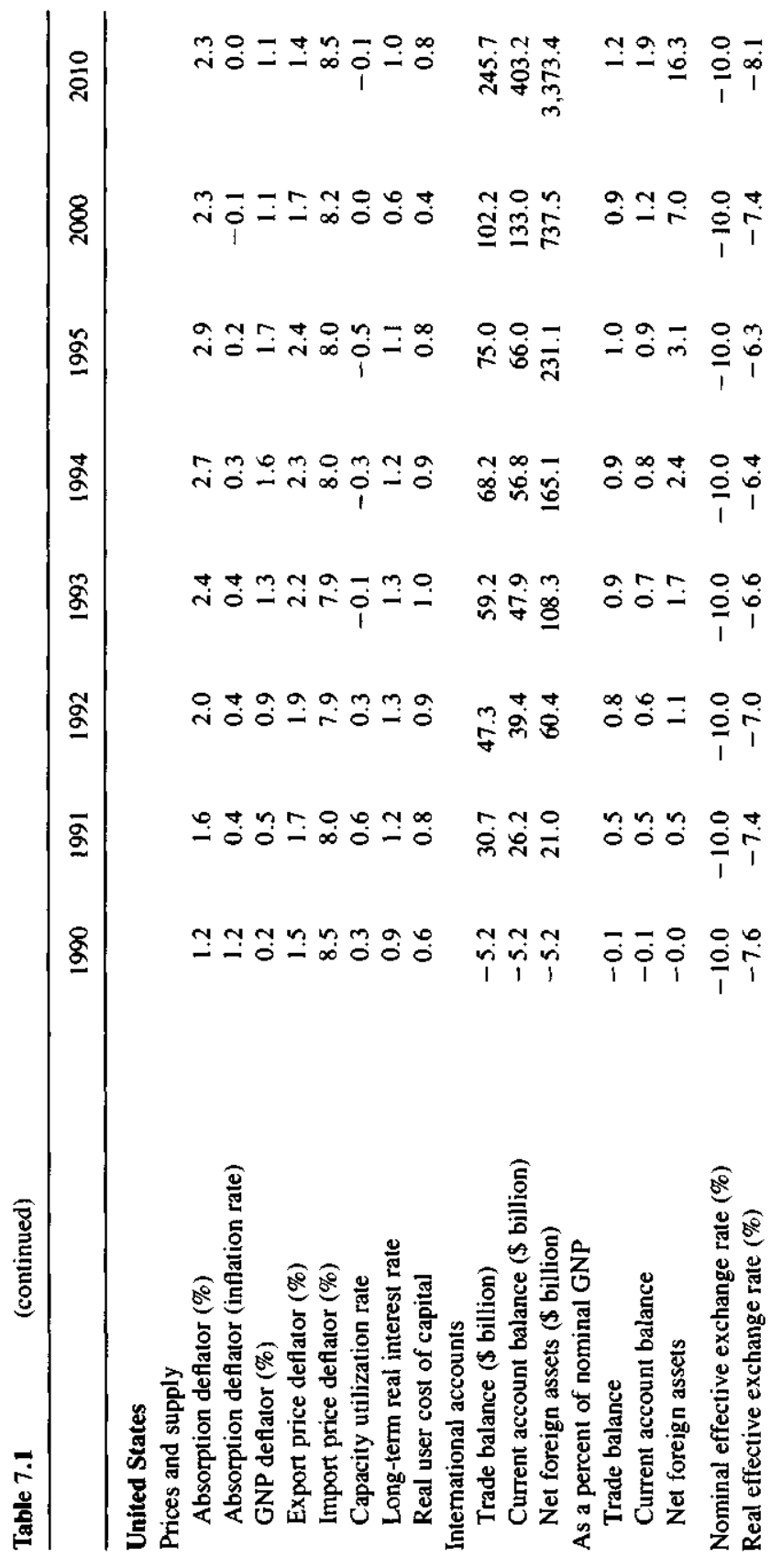




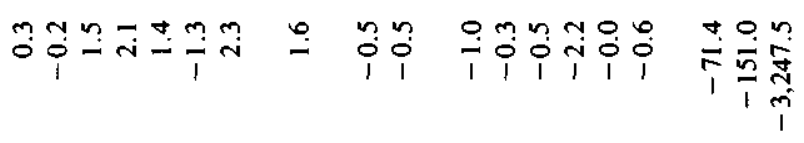



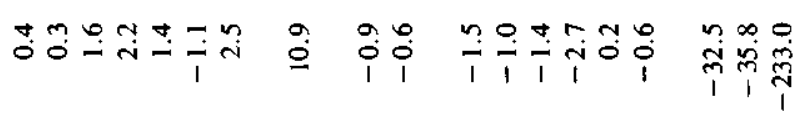







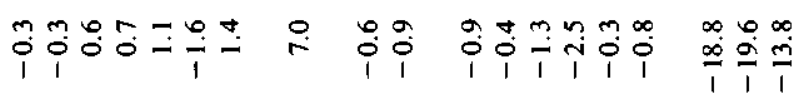

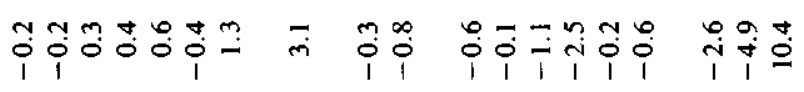

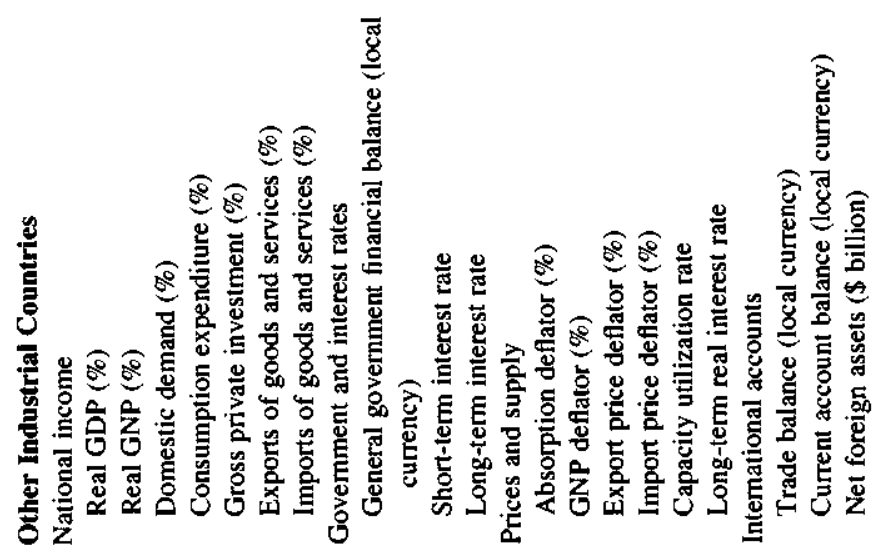




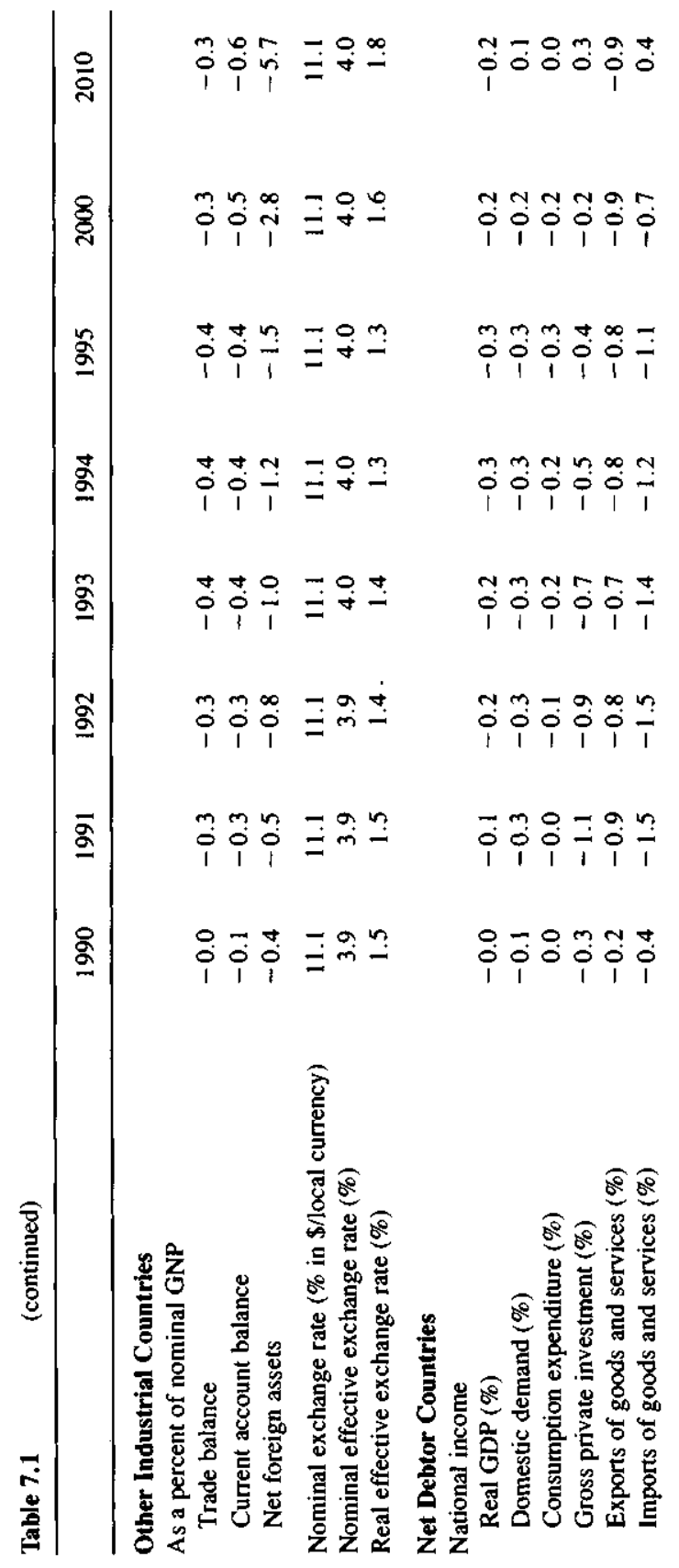




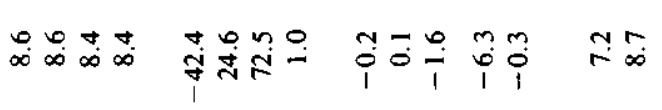

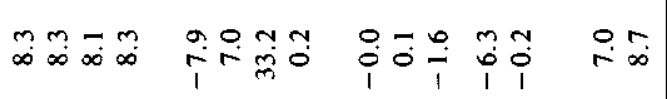

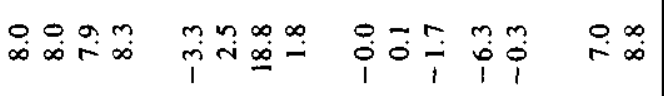



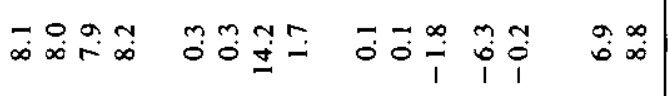

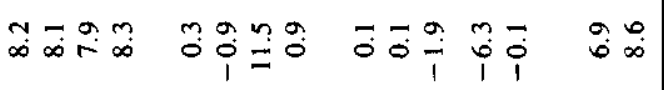

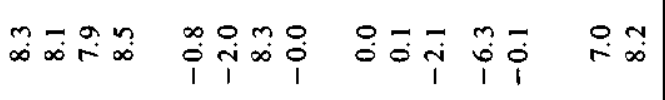



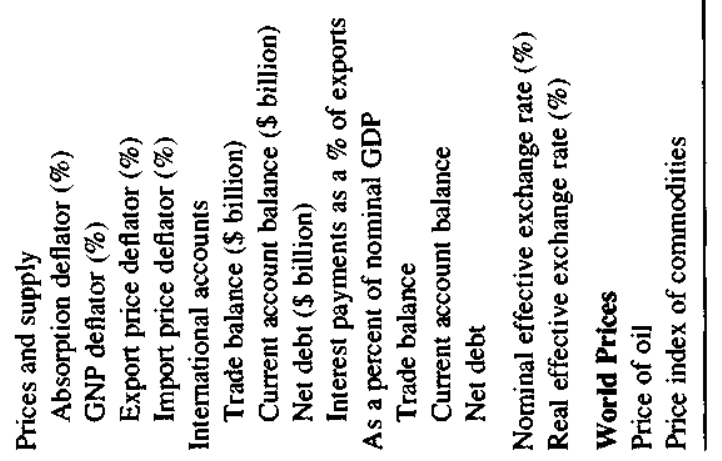


decline in domestic demand. Thus the exogenous nominal depreciation produces a permanent rise in the real interest rate and results in a permanent loss of output. In addition, it is worth noting that the dollar depreciation increases the domestic debt burden of the government. First, the increase in interest rates increases the servicing of the existing stock. Second, real output declines, reducing the tax base. Lastly, nominal government spending and taxes both rise with inflation, but since the government balance is initially in deficit, the rise in domestic prices worsens the deficit.

In general the effect on the aggregate of the other industrial countries is the mirror image of the United States, although the deviations are more modest. The exchange rate change for each of these countries is smaller than for the United States in effective terms, since each country is depreciating against the dollar but remaining unchanged against the other currencies. The developing countries are detrimentally affected by the dollar depreciation as exports from this region decline. Combined with the rise in U.S. interest rates, foreign financing, and therefore imports, decline. Since imports are the primary source of capital formation, output declines over the medium term.

\subsection{Endogenous Premia and External Sustainability}

In this section we examine, through simulations of MULTIMod, the possible effects of international investors demanding a premium on holding dollar assets if the U.S. net foreign asset to GNP ratio is expected to deviate from some arbitrarily specified exogenous level, assumed to be perceived by investors to be "sustainable." ${ }^{11}$ In the baseline scenario for MULTIMoD, discussed in section 7.2, the ratios of government debt and net foreign assets to GNP stabilize over the long run. These assumptions were made to allow the model to simulate around a reasonable steady state. The first simulation presented below, and shown in table 7.2, assumes that the decline in fiscal expenditures included in the arbitrary baseline does not materialize. Rather, fiscal expenditures are substantially above the baseline values. Since the paths for the fiscal variables in the baseline rest on a policy stance similar to Gramm-Rudmann, it is quite plausible to assume that these goals would not be achieved unless Congress and the White House significantly change their behavior. It appears that the anticipated peace dividends resulting from the easing of tensions in Eastern Europe will likely be spent on increased aid to this region or domestic programs. More precisely, we permanently increase fiscal expenditures by 5 percent of GNP above our baseline, phased in gradually over three years. ${ }^{12}$

The fiscal expansion results in a relatively small and temporary increase in U.S. output, with a substantial increase in the long-term nominal and real interest rates, although short-term rates actually fall on impact. ${ }^{13}$ With a prolonged increase in the real interest rate, domestic investment is persistently crowded out and the stock of capital falls over the long run, resulting in a permanent decline in capacity and hence output. The increase in domestic 
absorption and the appreciation of the real exchange rate produce a substantial increase in the trade deficit. The increase in U.S. nominal interest rates amplifies the deficit on the current account, and the net foreign asset position continues to deteriorate.$^{14}$ In fact, it appears that it is on an unstable path. The increase in government spending substantially raises the ratio of domestic government debt to GNP, results in a permanent increase in interest rates and a permanent appreciation of the nominal and the real exchange rate.

The U.S. fiscal expansion increases the output of foreign industrial countries, at least in the short run, primarily through the increase in foreign net exports. However, the appreciation of the dollar puts upward pressure on foreign domestic prices, creating a decline in the real money supply and an increase in interest rates. Therefore, output declines over the medium term because of a fall in both domestic consumption and real investment. The counterpart to the decline in the U.S. net foreign asset position is of course a rise in the net foreign asset position of the other industrial countries. The developing countries are not adversely affected by the U.S. fiscal expansion. Although net lending to the debtor countries falls as the increase in U.S. interest rates reduces the ability of these countries to service the debt, the U.S.induced increase in export revenues more than compensates and the developing countries are able to increase their imports.

As argued earlier, it seems unreasonable to believe that the industrial countries will continue to build up claims on the United States without some compensating increase in the rate of return on U.S. assets. MULTIMOD assumes that assets denominated in different currencies are perfect substitutes. Therefore, the primary channel remaining to return net asset stocks to their steadystate values is changes in consumption due to wealth transfers. Although these net foreign assets are part of total wealth and their change is rather substantial in the U.S. fiscal expansion, this component of financial wealth represents a relatively small fraction of total wealth. If the model were run for more than fifty years, eventually the change in the net foreign asset positions would dominate total wealth and domestic consumption would respond. ${ }^{15}$ But the assumption of perfect asset substitutability becomes less tenable as the size of interest payments made to foreign residents grows substantially, increasing the incentive for either an explicit or implicit default. This could take the form of new tax laws on income to foreigners or possibly some form of capital controls. ${ }^{16}$ Krugman (1988), for example, suggests that the United States, probably more than any other country, has the least incentive to abide by the rules of the game. Thus, it is likely that a premium of some form will become necessary for foreign investors to hold U.S. assets if the foreign asset to GNP ratio is expected to continuously worsen, as in this fiscal scenario. Branson and Marchese (1988) posit the existence of such a premium on portfoliobalance grounds.

The approach used here is to assume that there is an arbitrary long-run level of the net foreign assets to GNP ratio, $\bar{f}$, that foreign investors perceive as 


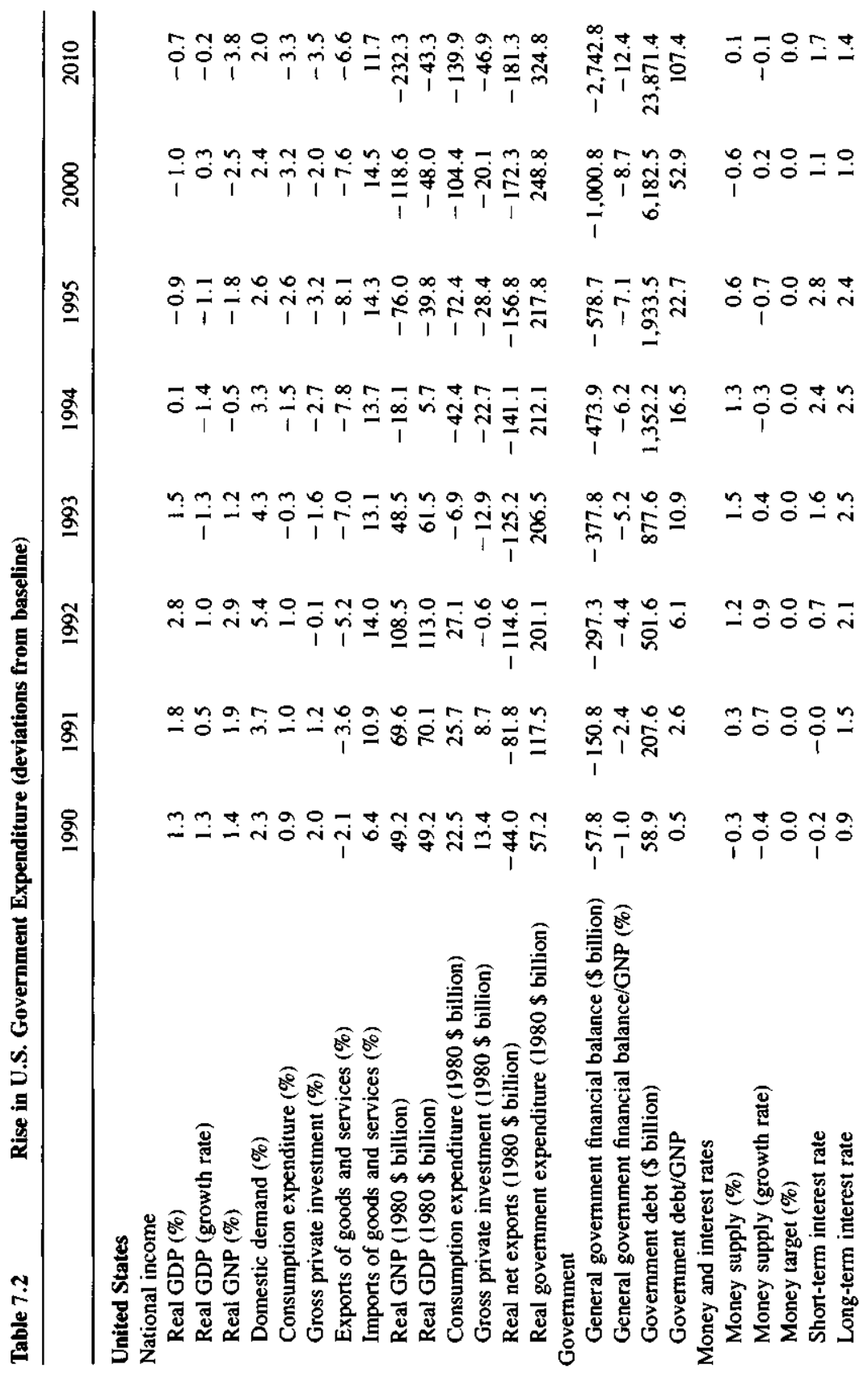




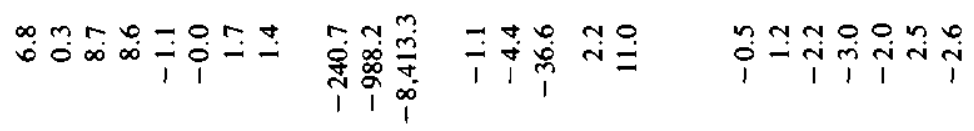

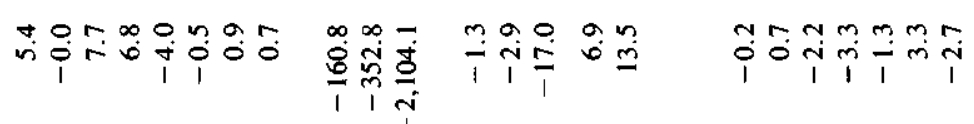

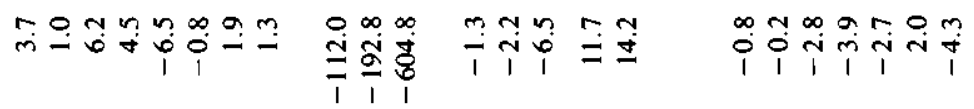

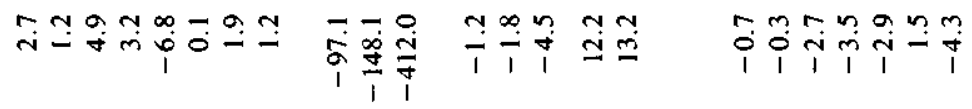

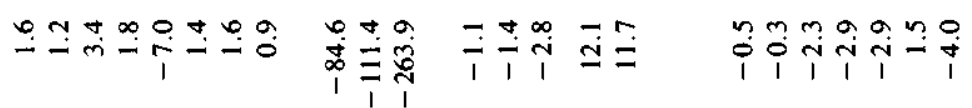

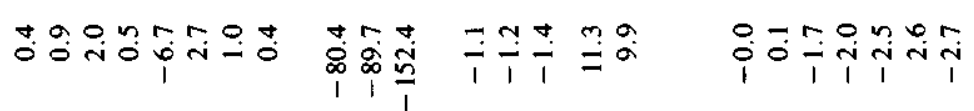

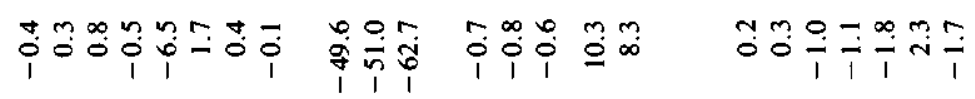

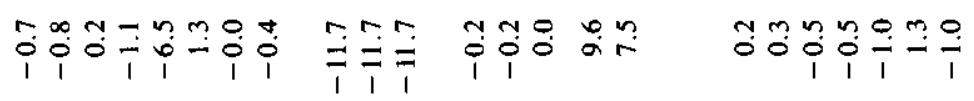

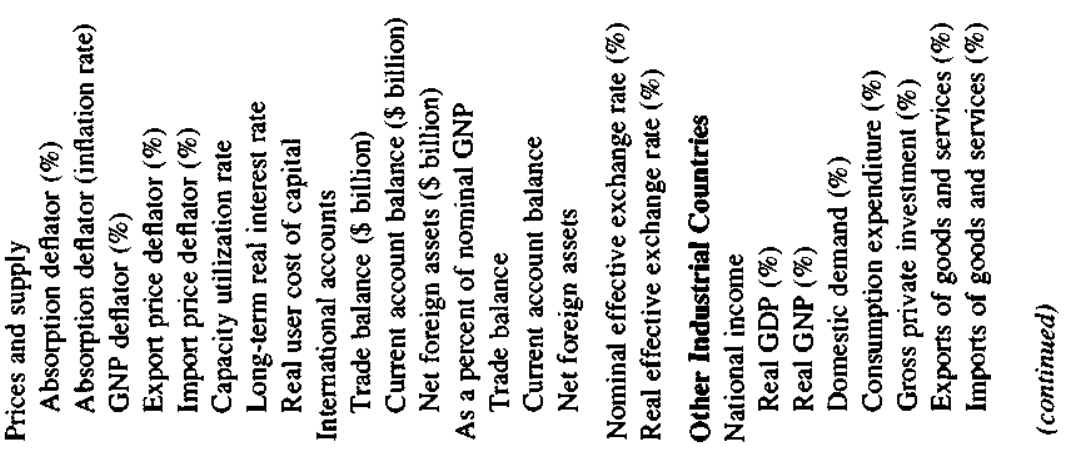




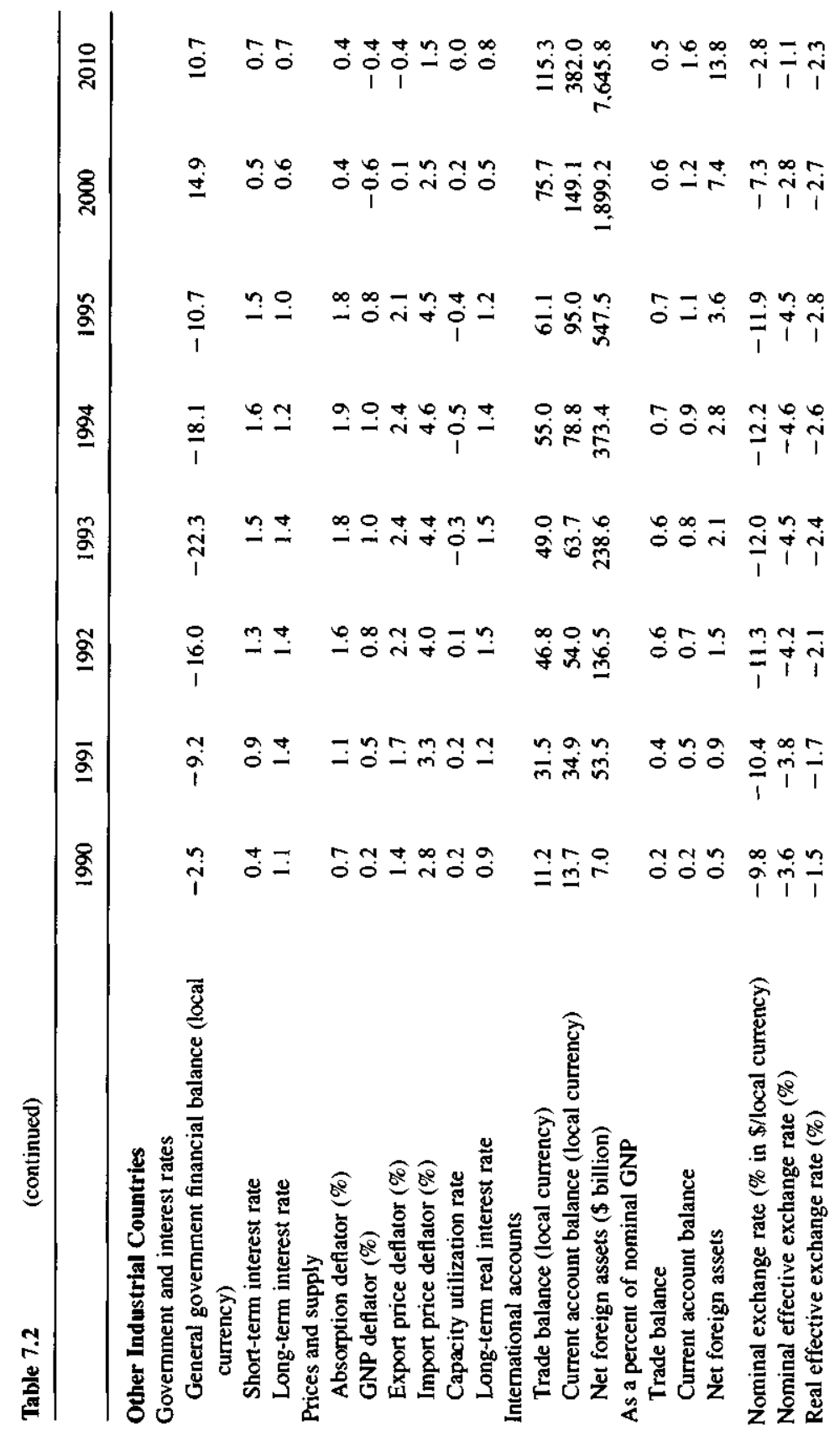






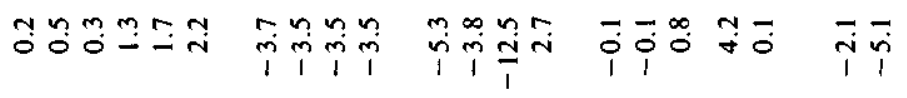

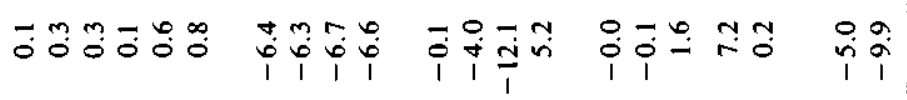

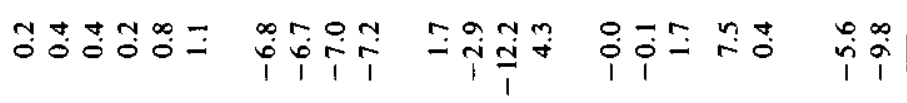

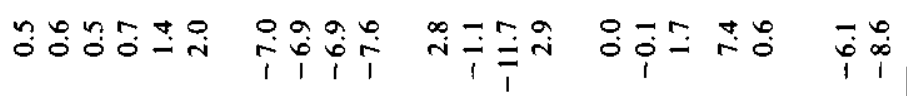



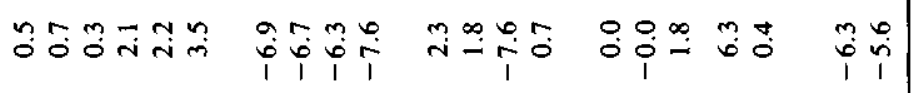

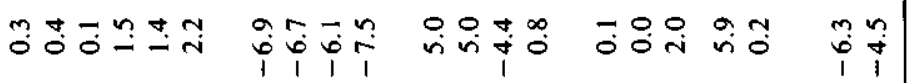




"sustainable." Investors will demand a premium if it appears that, ex ante, the ratio would deviate from this level because of policy changes or exogenous shocks. We assume that the premium is constant over time and, if the system is stable, the magnitude is enough to force the net foreign asset to GNP ratio back to this prespecified level over a specific time period (twenty years, in this paper). The rule used here is somewhat arbitrary, and it is easy to imagine alternative functional forms. Nevertheless, it provides a useful, model-based way to capture "rational runs" on a currency. Some alternative functional forms are discussed below.

The mechanics of the rule are as follows. We first define a currency premium, $\eta$, and a predetermined target value of the foreign asset to GNP ratio, $\bar{f}$. The value of $\eta$ is determined such that $f_{T}$ converged to $\bar{f}$ when $\eta$ is added to the interest-arbitrage condition

$$
(1+i)=\left(1+\mathrm{i}^{*}\right) \cdot\left(e_{t+1} / e_{\imath}\right)+\eta,
$$

where $i^{*}$ and $e$ are defined, respectively, as multilaterally weighted foreign nominal interest rates and the exchange rate (defined as the number of units of the domestic currency for a unit of the foreign currency) ${ }^{17}$ In order to solve for the equilibrium value of $\eta$ that is consistent with the underlying model and satisfies the above $\bar{f}$ convergence condition, we used the following iterative process. There are eight industrial countries or regions in the model. Therefore we included premia for $N-1$, or 7 countries; the United States was the excluded country. The first step in the procedure is to run a number of simulations on the model. For a specific currency, $j$, we shock $\eta$ by adding an arbitrary value to $\eta$ in equation (4) for the jth currency. We then calculate a vector composed of $\Delta f_{T}^{i} / \Delta \eta^{j}$, for $i=1$ to 7 . We then calculate the other six $j$ vectors by shocking $\eta$ for the other currencies. We refer to the full $7 \times 7$ derivative matrix as $Z$. The matrix $Z$ is the matrix of (numerical) derivatives of changes in net foreign asset to GNP ratios with respect to changes in the premia.

Taking the first-order Taylor expansion of $f_{T}(\eta)$, the equation $f_{T}(\eta)=\tilde{f}$ can be written

$$
f_{T}^{k}=\bar{f}-Z \cdot \Delta \eta,
$$

where $f^{k}{ }_{T}$ is the vector of values of the net foreign asset ratio from any simulation of the model in which $\eta$ is initially set to zero. Solving (5) for $\eta$, we get

$$
\eta^{k+1}=\eta^{k}+Z^{-1} \cdot\left[\bar{f}-f_{T}^{k}\right] \text {. }
$$

We then add these new values of $\eta$ to the model, re-solve the model, and recalculate (6) until $\eta$ converges.

Table 7.3 shows the deviations from the baseline scenario of the combined effects of the premia behavior described above and the fiscal shock. The weighted premium against the dollar turned out to be 1.08 percentage points. 
Compared to table 7.2 , we find that there has been a substantial reduction in the net foreign asset position of the United States. Although equation (6) implies that there should not be any deviation in the net foreign asset position for any country, the results show modest deviations: for the United States, the deviation is reduced from -36.6 to -4.4 percent by the year 2010 ; the aggregate of the other industrial countries shows a deviation from the baseline of 1 percent in 2010 compared to 14 percent in the pure fiscal shock. This is because MULTIMOD includes two developing country regions that are not represented in (6), and thus their net foreign asset positions were allowed to deviate from $\bar{f}$. Since world net foreign assets sum to zero in the model and all industrial countries except the United States reduce the deviations of their $f$ ratios to approximately zero, as implied by equation (6), the negative of the developing country deviation shows up in the U.S. position.

The U.S. dollar, which appreciated in the pure fiscal scenario, now depreciates by 14 percent, although the year-on-year premium is small-little over one percentage point. These results present a "hard landing" for the dollar. While the nominal exchange rate depreciates on impact and hovers permanently in this new range, the real exchange rate depreciates on impact and then appreciates, regaining its baseline level almost exactly by 2010 . Short and long, real and nominal interest rates rise by considerably more than in the previous scenario. Moreover, note that the difference in the increase in interest rates between the two scenarios increases over time; that is to say, the effect on interest rates of an increase in the premium against the dollar increases over time. Thus, the financial squeeze resulting from the portfolio shift away from dollar assets increases over time.

This "hard landing" imposes considerable long-run costs on the United States. While output in the United States shows a rather substantial increase on impact, even larger than in the pure fiscal expansion because of an expansion of exports accompanying the exchange rate depreciation, the gain is short lived. After five years, output is below its baseline level and the growth rate is down by two percentage points. Moreover, the long-run decline in capacity, and hence output, is larger. While the dollar depreciation does help the foreign sector, the higher real interest rates seriously discourage domestic consumption and investment. The higher U.S. interest rates also directly increase the domestic and foreign debt-service burdens. There is a worsening of the general government financial balance as a result of increased debt service, an increase in the nominal value of fixed government expenditure in real terms, and a decline in tax revenues as the tax base declines. The brunt of the adjustment required is therefore borne by domestic consumption and investment.

For the other industrial countries, the dollar depreciation causes some short-run costs in the form of a decline in output through net exports, but encourages modest long-term growth through the decline in interest rates. In the pure fiscal scenario, these countries experienced higher interest rates and a long-term loss of output. For the developing countries, this outcome is 


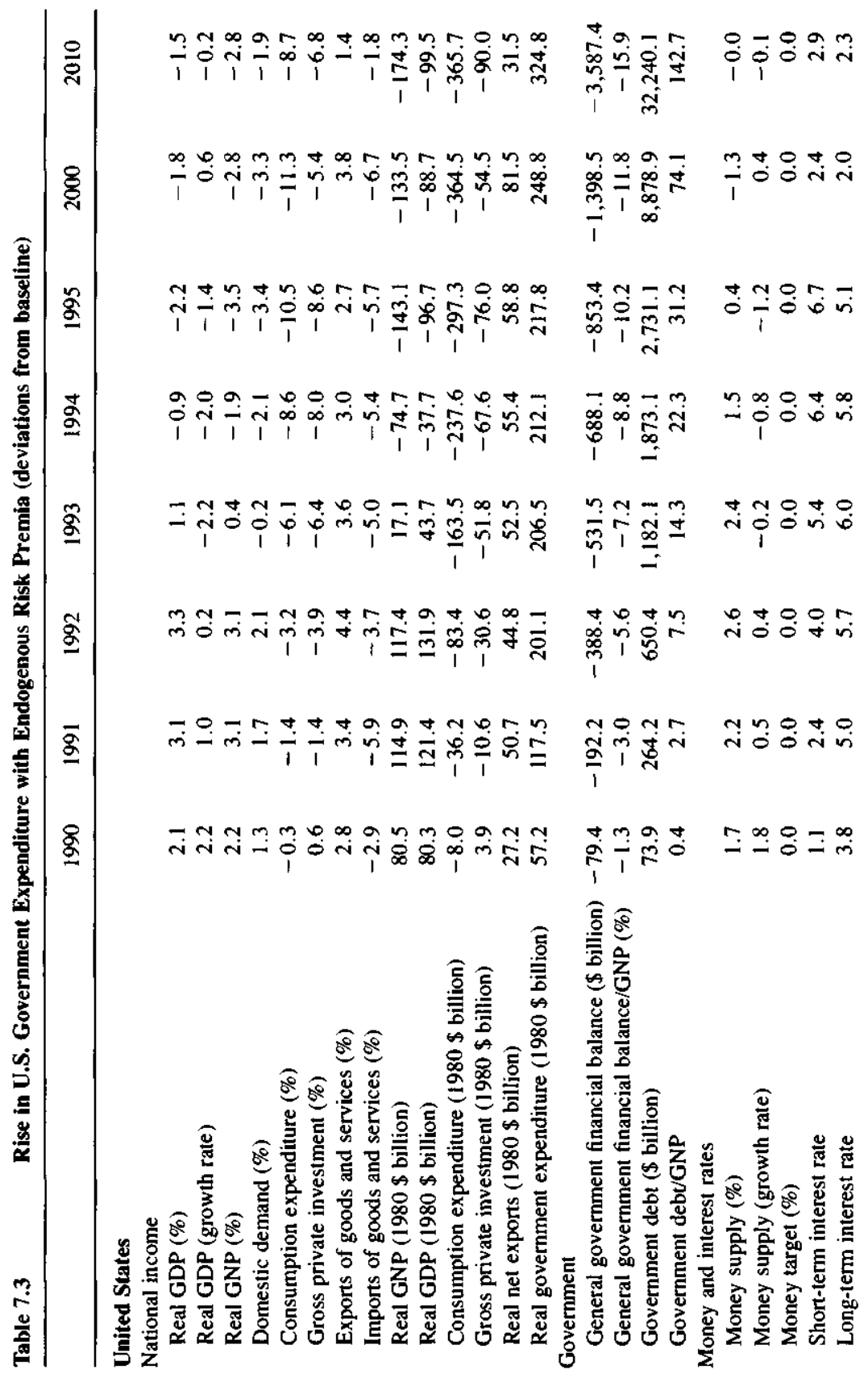




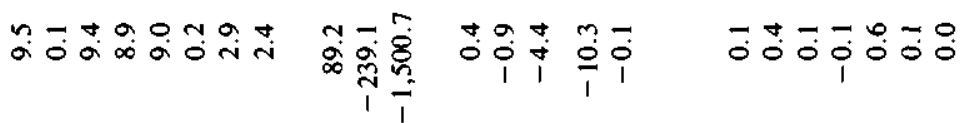

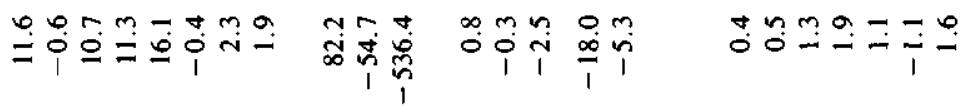

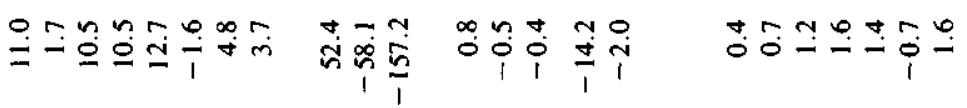



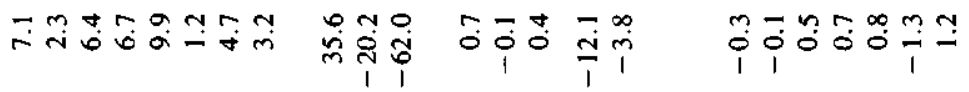

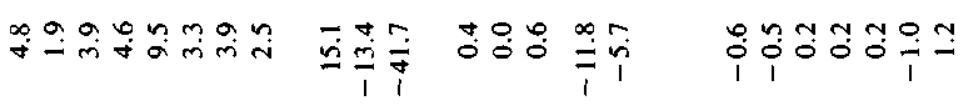

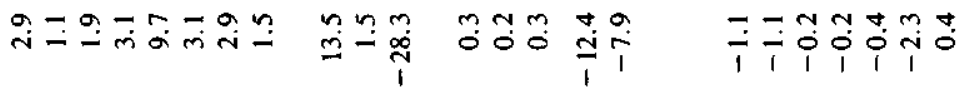

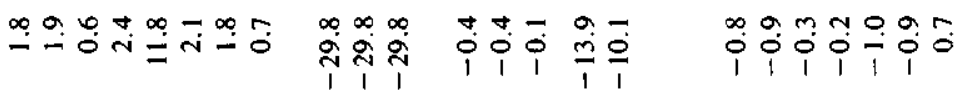

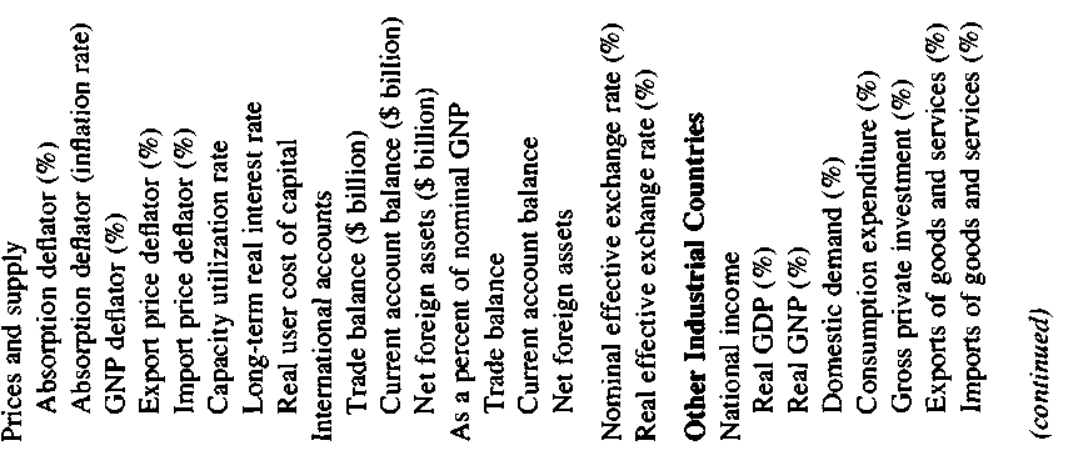









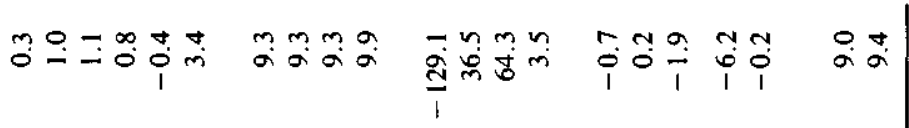

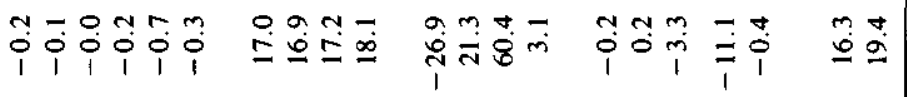

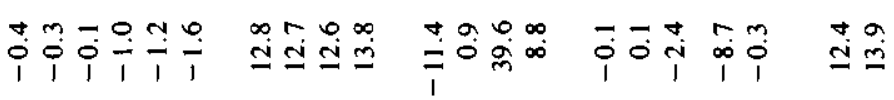







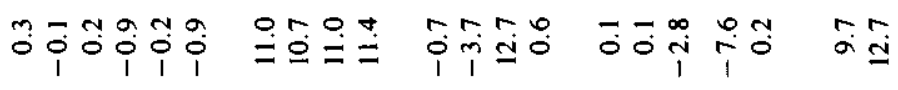

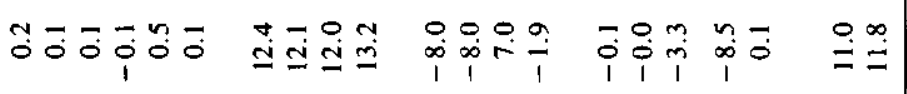

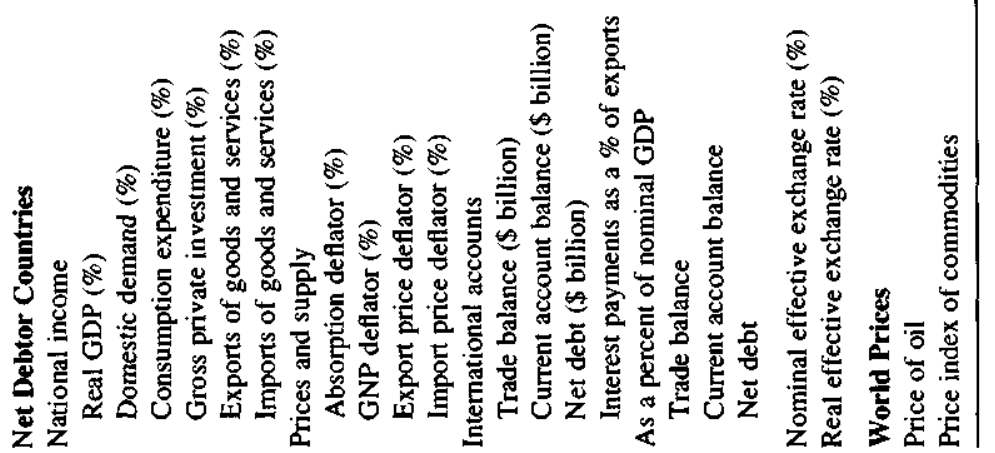


worse than the pure fiscal expansion, primarily because of the increased burden of higher U.S. interest rates.

It is interesting to note that a relatively small premium of little over one percentage point a year can bring about sizable movements in exchange rates-a 14 percent nominal and a 10 percent real depreciation on impactand over time can cause a substantial movement in the $f$-ratio-more than 32 percentage points in twenty years. This accords well with the observation that though large changes in exchange rates have been observed in the 1980s, observed ex post risk premia have been small.

The functional form employed above describing the dependence of the premium on expected future $f$ positions is, as stated earlier, arbitrary. Branson and Marchese (1988) instead, posit time-varying premia as functions of the contemporaneous level of $f$. We do not implement such a functional form, primarily because of the potential existence of perverse short-run effects due to the presence of J-curve effects on trade balances, and valuation effects on past holdings of stocks of foreign assets. ${ }^{18}$

\subsection{Conclusion}

The sustainability of the U.S. external position hinges on the willingness of international investors to add, on net, U.S. liabilities to their portfolios. We have argued that investors are unlikely to allow a "large" build-up of such claims, and an important question is therefore the likely consequences of an unwillingness on their part to add such claims to their portfolios. We have modeled the effects of foreign investors imposing a "sustainable" foreign asset ratio on the United States by positing the existence of a premium on dollar assets when the foreign asset position is expected to deviate from this level. The process presents an example of a self-correcting mechanism for attaining external balance. The results show that the premia required may be modest for "correcting" potentially large movements in net foreign asset positions. However, the costs of such an imposed adjustment can be substantial in terms of lost output. Moreover, the results suggest that in the absence of a fiscal correction, this imposed external adjustment is likely to worsen the fiscal situation, thus increasing the costs of adjustment in terms of private consumption, investment, and hence future output.

\section{Notes}

1. Various observers have argued that official U.S. statistics overstate the U.S. net foreign liability position. See Ulan and Dewald (1989) and Danker and Hooper (1990). It seems indisputable, however, that there has been a substantial decline in the position.

2. For a general discussion of movements in such ratios, see Dooley et al. (1986).

3. And what the path of the ratio may look like with unchanged behavioral responses. Krugman (1985, 1988) conducts a similar analysis. 
4. The ratio was computed as $f_{t}^{*}=-f_{t} \cdot\left(\mathrm{GNP}_{t} / \mathrm{GNP}_{t}^{*} \times 3\right)$, where the asterisk denotes the rest of the industrial countries. For assumptions on the path of foreign variables, see the IMF's World Economic Outlook (October 1989).

5. The version of the model we used is based primarily upon Masson, Symansky, and Meredith (1990). However, some of the changes in the model that are described in that paper are very recent and are not incorporated in our version of MULTimod. See also Masson et al. (1988) for a description of the first version of MULTIMOD.

6. The form of the interest-rate reaction function does allow for modest deviations of the exchange rate from its target.

7. These are not official IMF assumptions.

8. A simulation is a useful way to understand some of a model's properties. In this section we limit ourselves to an exchange rate scenario. The impact of fiscal and monetary shocks in MULTIMOD are described in detail elsewhere; see Masson et al. (1988) and Masson, Symansky, and Meredith (1990). In addition, a fiscal scenario is discussed in section 7.4 .

9. In most models, a constant depreciation of the currency is produced by assuming an exogenous path of the exchange rate and calculating the "add factor" in an exchange rate (or capital account) equation that is consistent with the pre-specified path of the exchange rate. To produce a constant percentage change in the exchange rate in a backward-looking model, the "add factor" risk premium declines over time, while in a forward-looking model, the risk premium increases over time.

A similar analysis was carried out using twelve econometric macro models as part of the Brookings Conference on Empirical Macroeconomics for Interdependent Economies. Detailed tables illustrating the effects of a dollar depreciation for these twelve models can be found in the conference proceedings, collected in a volume edited by Bryant et al. (1988).

10. See Branson and Marchese (1988) for a discussion of the effects of an exogenous change in the exchange rate in both a small theoretical model and in simulations using MULTIMOD and the OECD's INTERLINK model.

11. In a more fully specified model, the determination of such a ratio would, of course, be endogenous. See Dooley and Isard (1987) for discussion of a framework in which such a ratio would be endogenously determined.

12. One change in the structure of MULTIMOD was made for this simulation. MULTIMOD includes a rule that alters taxes to hit a steady-state level of the ratio of government bonds to GNP. This tax reaction function was turned off.

13. If the fiscal expansion was a once and for all change instead of the gradual path used in this simulation, the short-term interest rate would have increased.

14. In the model it is assumed that all external debt is denominated in dollars. The term-structure of debt incurred is assumed to remain constant. In particular, it is assumed that 50 percent is short term, and the other 50 percent long term, which is rolled over every three years.

15. Horne, Kremers, and Masson (1989) attempt to identify empirically relevant channels for external adjustment.

16. The recent change in U.S. tax laws that substantially alters the tax burden on inheritance due non-U.S. residents from assets owned in the United States is an example of a scheme to reduce the return on U.S. assets owned by foreigners.

17. In MULTIMOD, the interest-parity condition is written as a set of bilateral equations with respect to the dollar. Since the model does not account for bilateral foreign asset positions, the arbitrage condition was redefined in multilateral terms in order to use the aggregate foreign asset position in the calculation of $\eta$.

18. Branson and Marchese (1988) do not allow for J-curve effects. Krugman (1989b) considers the effects of a once and for all exogenous change in the risk premium against the dollar in a model incorporating $\mathrm{J}$-curve effects on the trade balance. 


\section{References}

Branson, William. 1985. Causes of appreciation and volatility of the dollar. In The U.S. Dollar: Prospects and Policy Options. Federal Reserve Bank of Kansas City.

Branson, William, and Grazia Marchese. 1988. Intemational imbalances in Japan, Germany, and the U.S. Mimeo, October.

Bryant, Ralph C., Dale W. Henderson, Gerald Holtham, Peter Hooper, and Steve Symansky, eds. 1988. Empirical Macroeconomics for Interdependent Economies, supplemental vol. Washington, DC: The Brookings Institution.

Danker, Deborah, and Peter Hooper. 1990. Intemational financial markets and U.S. extemal imbalance. International Finance Discussion Paper, no. 372 (January). Washington, DC: Board of Govemors of the Federal Reserve System.

Dealtry, Michael, and Josef Van't dack. 1989. The U.S. extemal deficit and associated shifts in intemational portfolios. BIS Economic papers, no. 25. Basle, Switzerland.

Diaz-Alejandro, Carlos F. 1984. Latin American Debt: I don't think we are in Kansas anymore. Brookings Papers on Economic Activity 2:335-89.

Dooley, Michael, William Helkie, Ralph Tryon, and John Underwood. 1986. An analysis of extemal debt positions of eight developing countries through 1990. Journal of Development Economics 21:283-318.

Dooley, Michael, and Peter Isard. 1980. Capital controls, political risk, and deviations from interest rate parity. Journal of Political Economy 88(2):370-84.

. 1981. The portfolio-balance model of exchange rates and some evidence that risk premiums are small. Mimeo, Board of Govemors of the Federal Reserve System.

. 1983. The portfolio-balance model of exchange rates and some structural estimates of the risk premium. IMF Staff Papers 30(4):683-702.

- 1986. Tax avoidance and exchange rate determination. Intemational Monetary Fund, DM/86/1.

. 1987. Country preferences, currency values and policy issues. Journal of Policy Modeling 9(1).

Home, Jocelyn, Jeroen Kremers, and Paul Masson. 1989. Net foreign assets and international adjustment in the United States, Japan and the Federal Republic of Germany. Intemational Monetary Fund, Working Paper no. 22.

Krugman, Paul. 1985. Is the strong dollar sustainable? In The U.S. Dollar: Prospects and Policy Options. Federal Reserve Bank of Kansas City.

- 1988. Long-run effects of the strong dollar. In Misalignment of Exchange Rates: Effects on Trade and Industry, ed. R. Marston, 277-94. Chicago: University of Chicago Press.

- 1989a. Exchange Rate Instability. Cambridge, Mass.: MIT Press.

1989b. The J-curve, the fire sale, and the hard landing. American Economic Association Papers and Proceedings 79(2):31-35.

Masson, Paul R., Steven Symansky, Richard Haas, and Mike Dooley. 1988. MULTIMOD: A Multi-Region Econometric Model. IMF Staff Studies for the World Economic Outlook (July):50-104.

Masson, Paul R., Steven Symansky, and Guy Meredith. 1990. MULTIMoD: Mark II, The G-7 Version. IMF Occasional Paper, no. 71 (July).

Ulan, Michael, and William G. Dewald. 1989. The U.S. net intemational investment position: The numbers are misstated and misunderstood. U.S. Department of State, Washington, D.C. 